\title{
Corrigendum Systematic derivation of a surface polarisation model for planar perovskite solar cells - CORRIGENDUM
}

\author{
N. E. COURTIER, J. M. FOSTER, S. E. J. O'KANE, A. B. WALKER \\ and G. RICHARDSON
}

doi:10.1017/S0956792518000207 First published by Cambridge University Press 22 April 2018.

Following publication, errors were discovered in the y-axis labels of the electron and hole concentration plots in the following figure panels: figure $4 \mathrm{c}$, figure $4 \mathrm{~d}$, figure $5 \mathrm{c}$, figure $5 \mathrm{~d}$, figure $6 \mathrm{c}$, figure $6 \mathrm{~d}$, figure $8 \mathrm{c}$ and figure $8 \mathrm{~d}$. The error does not affect the description, analysis or conclusions. The correct representation of the figure panels are shown here.

(c)

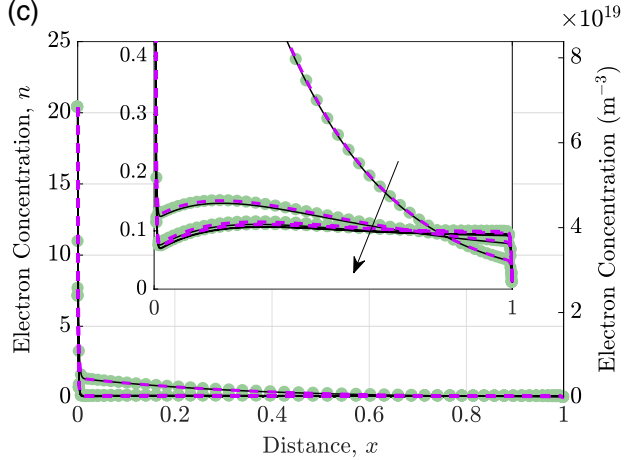

(d)

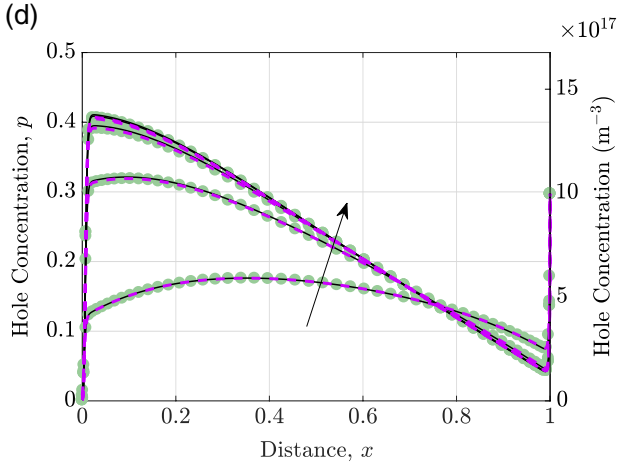

FIGURE 4.

(c)

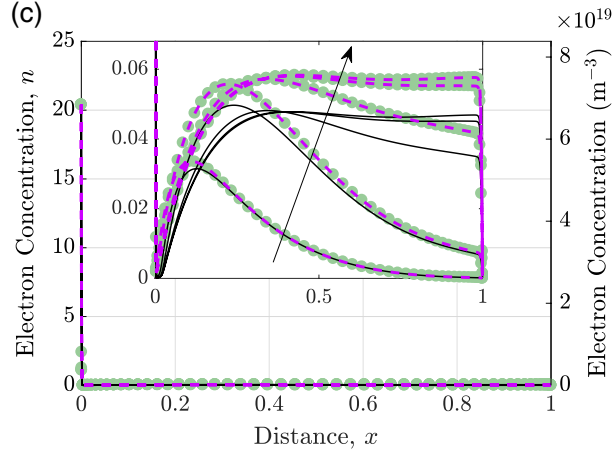

(d)

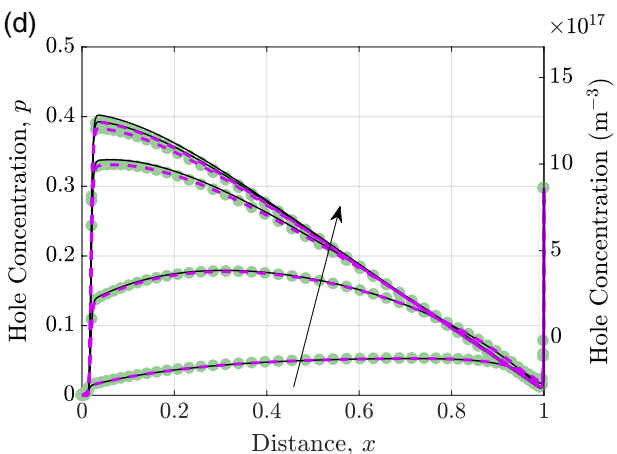

FIGURE 5. 

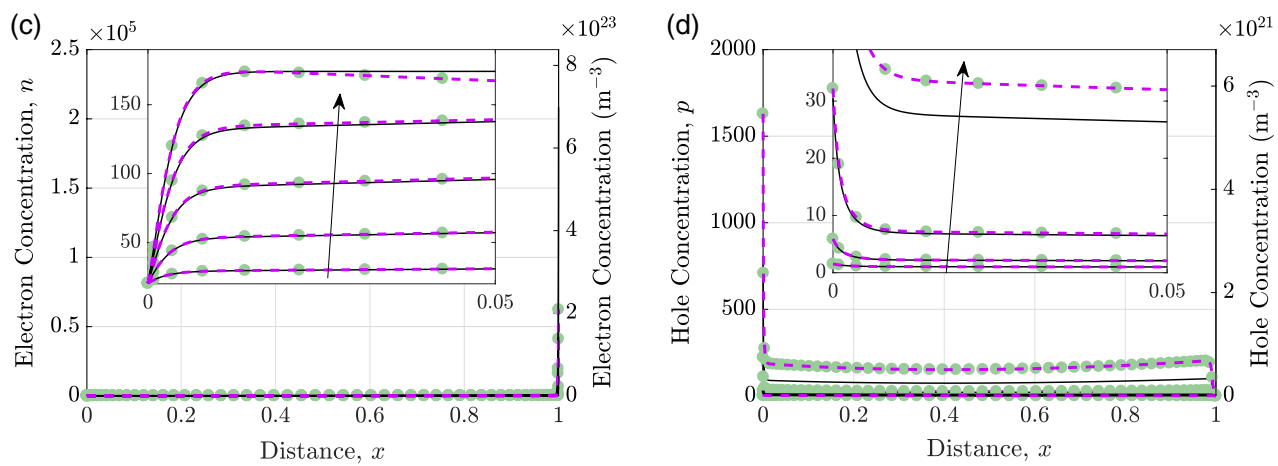

FiguRE 6.
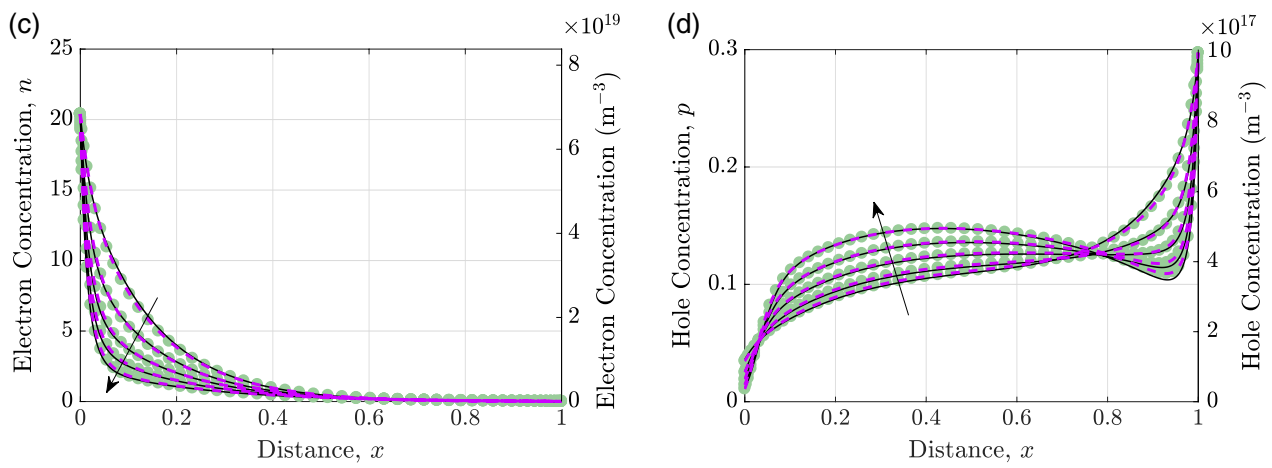

FigURE 8.

The authors apologise for the error.

\section{Reference}

[1] Courtier, N. E., Foster, J. M., O’Kane, S. E. J., Walker, A. B. \& Richardson, G. (2019) Systematic derivation of a surface polarisation model for planar perovskite solar cells. Euro. Jnl of Applied Mathematics 30, 427-457. 